\title{
The Nongovernmental Nature of Korean Businesses' Economic Exchanges with China prior to the Normalization of 1992
}

\author{
Cheon, Kyung-H ee*
}

(D ongguk University)

\section{$\langle$ CONTENTS〉}

I. Introduction

II. Background: The Way of Doing Secret Business

III. The Nongovernmental Nature of Korean Businesses' Economic Exchanges with China
1. The Changes in GovernmentBusiness Relations

2. The Circumstantial and Empirical Evidence

3. The Government's Financial Support IV. Summary and Conclusion

- Keyword: South Korea-China relations, South Korean businesses' economic activities with China, South Korea's nongovernmental economic relations with China.

\section{【ABSTRACT】}

Prior to the normalization of South Korea-China relations in 1992, South Korea's economic exchanges with China centered on trade and other related contacts. And South Korea's unofficial trade with China was mainly led by private businesses, especially 'big business groups' (or chaebol groups). Then, in relation to the dominant role of private businesses, one may ask whether Korean private businesses' economic exchanges with China over the period 1979-92 could be regarded as 'nongovernmental' in effect. Those who raise doubt about the nongovernmental nature of such Korean businesses' economic activities might suppose that Korea's unofficial economic exchanges with China were made possible largely by the Korean government's initiative or its active intervention and that thus they were not very nongovernmental. Although the subject on the basic

* The author would like to give thanks to anonymous reviewers (as well as Prof. Patrick Morgan and Prof. Dorothy Solinger at UC Irvine) for their kind advices and valuable comments on the draft of this paper. 
nature of Korean businesses' economic exchanges with China during 1979-92 has not received due scholarly attention, it is to be dealt with for further research on South Korea-China relations in general and theoretical research on South Korea's transnational economic relations with China prior to 1992 in particular. Thus, this study seeks to find an answer to the question by identifying the nongovernmental nature of Korean businesses' economic exchanges with China during the period of 1979-92.

To this end, this study begins with a discussion of the changes in governmentbusiness relations in Korea to consider the general business climate, then presents more circumstantial and empirical evidence supporting the nongovernmental nature of Korean businesses' economic exchanges with China, and finally comments on the Korean government's financial support for private companies involved in China business. As a conclusion, there is no evidence available to demonstrate that Korea's unofficial economic exchanges with China were explicitly directed or closely controlled by the Korean government; on the contrary, much circumstantial and empirical evidence supports that such Korean private businesses' economic exchanges were nongovernmental, conducted by their own decisions, on their own initiative, for their own interests, and at their own risks, not by their government's close control, coordination or direction.

\section{I . Introduction}

The year 1979, when the Beijing government in effect sanctioned formerly illicit trade with South Korea and 'two-way' trade was initiated between South Korea and China, may be considered as the first year of unofficial economic exchanges between the two countries. During the years prior to the normalization of Beijing-Seoul relations in 1992, South Korea's unofficial economic exchanges with China centered on trade and other related contacts. ${ }^{1}$ And South Korea's trade with China was mainly led by private businesses, especially 'big business groups' (or chaebol groups). Indeed, by early 1988, almost all the major Korean chaebols had been involved in trade with China. ${ }^{2)}$ As

1) Compared with the magnitude of its trade with China, South Korea's investment in China was not so significant despite the potential effects of Korea's China investment on the development of Beijing-Seoul relations during the pre-normalization period. 
conglomerates, these large chaebol groups were financially strong enough to risk doing trade with China with which Seoul had no diplomatic ties. Moreover, they could arrange 'barter deals' with China, which experienced lack of foreign exchange to pay for its imports. Following big chaebol companies, beginning in early 1988, many smaller private firms were also directly involved in China business. ${ }^{3)}$ Thus, while a few public enterprises began direct dealings with China in the late 1980s, private businesses were the dominant actors in Korea's economic exchanges with China over the period under study.

In relation to the dominant role of private businesses (esp., chaebol groups), one may wonder if Korean private businesses' economic exchanges with China prior to the normalization of 1992 could be regarded as 'nongovernmental' in effect. Unfortunately, no serious study has been done previously on this question, but it deserves scholarly attention for theoretical research such as South Korea's transnational economic relations with China prior to 1992. As will be seen, what is certain is that there is little or no evidence available to demonstrate that trade and other economic exchanges with China conducted by Korean private businesses were explicitly directed or closely controlled by the Korean government. Thus, as suggested, this study will seek to find an answer to the question by identifying the nongovernmental nature of Korean businesses' economic exchanges with China during the period of 1979-92.

\section{II . Background: The Way of Doing Secret Business}

Before proceeding to our discussion, it will be necessary to take a look at the context in which South Korea's trade and other economic exchanges with China were conducted. As is widely known, during most of the years of 1979-92, South Korea's trade and other economic exchanges with China were conducted in indirect and secret ways. Needless to say, it was because North Korea's strategic importance to China acted as an apparent constraint on China's economic approach to the South. Indeed, to avoid offending the North, China had to make every effort to control the visibility of its trade with South Korea. Accordingly, during most of the 1980s, trade between South Korea and China was mainly indirect, conducted through various middlemen in Hong Kong; and most of

2) See Korea Times, 12 May 1988, in Foreign Broadcast Information Service (FBIS), Daily Report: East Asia (hereafter FBIS-EAS), 12 May 1988, pp.22-23.

3) See Robert Delfs, "Seoul's hi-tech lure across the Yellow Sea," Far Eastern Economic Review, 8 December 1988, p.21. 
the indirect trade took the form of 're-export' from Hong Kong, although some goods went through Japan, Singapore, and other third countries. ${ }^{4)}$ Moreover, even when Chinese goods (such as coal and grain) were shipped directly to the Korean ports, all the arrangements were made through Hong Kong middlemen, the cargoes were carried on third-country vessels (usually manned and owned by Koreans), and the final destinations were disguised by the use of false documents. ${ }^{5}$

In order to maintain secrecy, Chinese officials forced South Korean businessmen to keep their trade out of the public eye. Indeed, Korean manufacturers were asked to remove both country-of-origin labels and company names from their goods exported to China; and, when they failed to do so, the shipments of South Korean export goods were halted or even confiscated. ${ }^{6}$ Moreover, even when a contract was made indirectly between the two sides, the Chinese did not hesitate to pull out of the deal once it was exposed to the press. ${ }^{7}$ Under this context, South Korea's intelligence agencies also warned domestic companies doing trade with China to keep their business activities confidential. On the other hand, during most of the 1980s, the Korean government imposed strict regulations on reporting any economic contacts or exchanges with China. Although the press ban was in effect lifted in early 1988, Korean companies actually engaging in business dealings with China still remained sensitive to their Chinese partners' strong demand for keeping secret; therefore, they were reluctant to confirm any information and press reports about their ongoing deals with the Chinese. ${ }^{8)}$

As a result, such an indirect and secret way of doing business with China inevitably caused the Korean government to have much difficulty in gathering correct information or data about Korea's trade and investment with China. Indeed, up until the late 1980s, even major economic ministries in the Korean government did not know exactly the extent of two-way trade, not to mention in the earlier years prior to 1985 . $^{9)}$ In the case

4) Wall Street Journal, 17 May 1982, 30(E), and 22 August 1984, 29(E). Also see Jae Ho Chung, "South Korea-China Economic Relations: The Current Situation and Its Implications," Asian Survey 28 (October 1988), p.1035.

5) See Economist, 28 February 1981, p.68; Andrew Tanzer, "A diplomatic defection," Far Eastern Economic Review, 26 November 1982, p.22; Paul Ensor, "Grains of a secret," Far Eastern Economic Review, 4 April 1985, p.56; Washington Post, 28 April 1985, A21.

6) Wall Street Journal, 17 May 1982, 30(E) and 22 August 1984, 29(E).

7) For example, see Christian Science Monitor, 28 March 1985, p.12.

8) See Mark Clifford, "Seoul's Chinese puzzle," Far Eastern Economic Review, 3 March 1988, p.51; and Lho Joo-hyoung, "Korea Looks West - To China," Korea Business World, July 1988, p.15 and 18 .

9) As an example, Vice Minister of the Economic Planning Board (EPB) Kim Ki-hwan revealed in June 1985; "No one knows the extent of the trade between China and South Korea" (Los Angeles Times, 14 June 1985, Part IV, p.3). 
of Korean investment in China, the situation was much more serious. ${ }^{10)}$ These facts thus suggest that during most of the 1980s, the Korean government had clear limits in its capacity to closely monitor or trace Korean private businesses' trade and other economic activities with China.

\section{The Nongovernmental Nature of Korean Businesses' Economic Exchanges with China}

As seen above, up until the late 1980s, the Korean government was not very able to monitor private businesses' economic activities with China. This is certain evidence suggesting that Korea's private economic exchanges were not under close direction and supervision of government agencies. However, those who still remain skeptical about the nongovernmental nature of such Korean businesses' activities might suppose that Korea's unofficial economic exchanges with China during 1979-92 were made possible largely by the Korean government's initiative or its active intervention and that thus they were not very nongovernmental. This supposition probably arises from the conventional image of "Korea, Inc." a term which has been used to describe an unusual degree of government-business partnership in which the distinction between government and nongovernment or public and private is not clear. ${ }^{11}$

In this context, this study begins with a discussion on the changes in governmentbusiness relations in Korea, then presents more circumstantial and empirical evidence supporting the nongovernmental nature of Korean businesses' economic exchanges with China, and finally comments on the Korean government's financial support for private companies involved in China business.

\section{The Changes in Government-Business Relations}

Indeed, many studies in the 1980s on the relationship between government and business in Korea have much stressed the dominant position of government in relations with big business. However, most of these studies were mainly based on the experiences

10) As an example, data released by Korea' s EPB in February 1989 show greatly reduced or exaggerated amounts of investment by several Korean private companies.

11) On the notion of "Korea, Inc." see Leroy P. Jones and Il SaKong, Government, Business, and Entrepreneurship in Economic Development: The Korean Case (Cambridge: Harvard University Press, 1980), pp.66-69. 
of the 'developmental state' under the Park Chung-hee regime (1961-79). Nevertheless, they might leave the impression that this situation remained more or less intact during the 1980s. ${ }^{12)}$ But, as some studies done in the 1990s have concluded, since the early 1980s, Korea has experienced dramatic political, economic, and social changes; in the process, the balance of power has shifted between government and private businesses, i.e., chaebols; thus, the government-dominated 'symbiotic' partnership under the Park regime has been replaced by a more strained, conflictual, and competitive relationship. ${ }^{13)}$ This implies that during the 1980s, Korea witnessed significant changes in governmentbusiness relations and thus the stereotyped conventional image of "Korea, Inc." was far from the situation of the 1980s (and early 1990). Interestingly, it was in this time period that Korea's major chaebol groups were competing with each other to take the lead in advancing into the huge, potential market in China.

Here we have no need to go into details on the changes in government-business relations in Korea during the 1980s and early 1990s, but the 'general business climate' during this period is deemed to have affected the basic nature of Korean private businesses' economic exchanges with China. As will be seen in what follows, the relationship between government and business in Korea has changed mainly because of the government's anti-chaebol campaigns, the growth of chaebol power, and a transition to democracy in Korean politics and society.

Firstly, from the start, Chun Doo-hwan's military regime lacked political legitimacy due to his taking power through a military coup in December 1979 and his direction of the bloody suppression of the Kwangju uprising in May 1980. Moreover, during 1979-80, the Korean economy was faced with an acute crisis. ${ }^{14)}$ Therefore, both to secure popular

12) See Chalmers Johnson, "Political Institutions and Economic Performance: The GovernmentBusiness Relationship in Japan, South Korea, and Taiwan," in Frederic C. Deyo, ed., The Political Economy of the New Asian Industrialism (Ithaca, N.Y.: Cornell University Press, 1987), pp.136-64; Alice Amsden, Asia's Next Giant: South Korea and Late Industrialization (New York: Oxford University Press, 1989); and Robert Wade, Governing the Market: Economic Theory and the Role of Government in East Asian Industrialization (Princeton, N.J.: Princeton University Press, 1990).

13) See Chung-in Moon, "Changing Patterns of Business-Government Relations in South Korea," in Andrew MacIntyre, ed., Business and Government in Industrializing Asia (Ithaca, N.Y.: Cornell University Press, 1994), pp.142-66; and Eun Mee Kim, Big Business, Strong State: Collusion and Conflict in South Korean Development, 1960-1990 (Albany, N.Y.: State University of New York Press, 1997).

14) The following account mainly draws on Moon, ibid,; Chung-in Moon, "The Demise of a Developmentalist State?: Neoconservative Reforms and Political Consequences in South Korea," Journal of Developing Societies 4 (1988), pp.67-84; and Stephan Haggard and Chung-in Moon, "Institutions and Economic Policy: Theory and a Korean Case Study," World Politics 42 (January 1990), pp.210-37. 
support and to overcome the economic crisis, Chun's regime took a path different from the Park era. Based on the belief that tight connection between government and big business during the 1970s had created numerous problems and thus now became the target of public criticism, the Chun government began to attack big business through a series of aggressive policy measures. Indeed, the Monopoly Regulation and Fair Trade Law in April 1981 marked a decisive turning point in the Chun government's policy toward big business. And other anti-chaebol measures taken in the early 1980s were all designed to restrain the concentration of economic power in the hands of a small number of chaebol groups and to reduce the preferential treatment these chaebols had enjoyed under the previous regime. Of course, business reaction to the government's anti-chaebol campaigns was hostile; and more remarkable is that, unlike the Park era, chaebol groups made strong and public protests against government policies or directives. Thus, there were continuous conflicts and strains between the Chun government and big business, during the first half of the 1980s in particular. ${ }^{15}$

The rift between government and big business continued under the Roh Tae-woo regime (1988-93). ${ }^{16)}$ In the face of widespread resentment among the general public against big business, Roh first sought to distance himself from chaebol groups but soon launched a campaign to check the economic dominance of chaebol groups. In May 1990, the Roh government ordered the 49 largest groups to sell by year's end their huge holdings of nonproductive real estate that the government claimed were being held for speculative purposes. As a Korean observer has described, the May 1990 move was nothing but Roh's declaration of "war against the chaebols." ${ }^{17)}$ As expected, this drastic measure provoked strong resistance on the part of big chaebols; such a business tycoon as Chung Ju-yung, founder of the Hyundai group, showed chaebol groups' displeasure by severely criticizing both Roh and his government. The chaebols' hostility to the government remained unabated during the rest of Roh's term, because his government attempted to make use of attacks on the chaebols as a means to gain votes from the public in the upcoming elections of 1992.

In short, over the 1980s and early 1990s, the Korean government attacked big business by adopting various policy measures contrary to chaebol interests for political as well as

15) For moe on the conflicts between the government and chaebols during 1980-85, see Mark L. Clifford, Troubled Tiger: Businessmen, Bureaucrats, and Generals in South Korea (Armonk, N.Y.: M. E. Sharpe, 1994), chaps.13-16.

16) The following account mainly draws on Moon (1994), pp.153-60; and Uhm Ji-do, "No daetongryeong ui jaebeol gwa ui jeonjaeng" [President Roh's war against the chaebols], Wolgan Chosun [Monthly Chosun], June 1992, pp.322-45.

17) Uhm, ibid., p.337. 
economic purposes. But each policy measure to limit the sphere of chaebol activities met with strong resistance and thus achieved limited success. ${ }^{18)}$ The result was mutual distrust and antagonism between government and big business, a far cry from the popular image of "Korea, Inc." usually characterized by close public-private consultation and cooperation.

A second, but more fundamental, factor contributing to the changes in governmentbusiness relations in Korea during the 1980s was the growth of chaebol power. In fact, it was during the 1970s that Korean chaebols grew into large-scale business groups, which was made possible by the Park regime's financial support through subsidized bank loans. In consequence, by the end of the 1970s, major chaebol groups came to dominate the Korean economy. Indeed, these chaebols had grown to the extent that they could call for a shift in the style of national economic management from the 'government-led' to a 'private-initiated' economy, i.e., an economy free from government intervention in private business activities. In the late 1970s, the Korean government began to be overwhelmed by the growing chaebol power and thus began to lose its control over the private sector. ${ }^{19)}$

Coming into the 1980s, the Chun government undertook wide-ranging economic reforms to correct various structural problems caused by government-led growth strategies under the previous regime. The general direction of Chun's reforms was thus to achieve 'economic liberalization' based on private initiative, less government intervention, and more market mechanisms. ${ }^{20)}$ But the liberalization drive notably increased the relative autonomy and power of the chaebols by reducing their dependence on the government. The trend was obviously reflected in the financial sector. In fact, over the 1960s and 1970s, Korea's financial system had been under complete control of its government; and, government-regulated finance (i.e., bank credit and foreign loans) had been the most effective policy tool for assuring business compliance and cooperation with government policies or direction. Accordingly, a credit-based financial system had been the basis of "Korea, Inc." ${ }^{21)}$ In this context, liberalization of the financial system in the early 1980s was of great significance in that it certainly represented the most

18) See Choi Cheong-lim, "Hanguk eun jaebeol gonghwaguk inga" [Is Korea the Republic of Chaebols?], Wolgan Chosun, October 1986, pp.220-25.

19) See Jong-Chan Rhee, The State and Industry in South Korea: The Limits of the Authoritarian State (New York: Routledge, 1994), p.79, 103 and 232.

20) For Chun's economic reforms during the 1980s, see Il SaKong, Korea in the World Economy (Washington, D.C.: Institute for International Economics, 1993), chap.4.

21) Jung-en Woo, Race to the Swift: State and Finance in Korean Industrialization (New York: Columbia University Press, 1991), p.149. 
fundamental change in government-business relations in Korea. ${ }^{22)}$

As the Korean government privatized all nationwide commercial banks between 1981 and 1983 by selling its share, big chaebol groups could enter the banking industry and managed to acquire controlling shares of the banks in indirect ways. ${ }^{23)}$ On the other hand, by abolishing preferential bank lending rates in 1982, the government lost its policy tool (i.e., the allocation of preferential bank credit) that had been used to control business behavior. But, more substantial changes in the financial system occurred in the non-banking sector. In the first half of the 1980s, the government's tight control over bank loans and its deregulation of the non-banking sector led to the explosive expansion of 'non-bank financial institutions' (NBFIs), thus providing chaebol groups with more diversified sources of corporate funds. ${ }^{24)}$ Moreover, in the second half of the 1980s, the stock market emerged as a new, major source of funds with a hike in stock prices in the 1986-89 years. ${ }^{25}$ ) Thus, during the 1980s, NBFIs and the securities market were the main pipelines for financing chaebol groups. In short, with financial liberalization, the government came to lose its useful tools for eliciting business compliance or cooperation with its policies, while the chaebols could enhance their financial autonomy by diversifying their sources of funds and thus by reducing their dependence on government-controlled finance. As a result, chaebol groups became better able to resist or evade government policies or direction, while the government was increasingly unable to control, monitor or coordinate the activities and behavior of chaebol groups. ${ }^{26)}$

Finally, a transition to democracy which began in 1987 accelerated the changes in government-business relations in Korea. In late June 1987, Roh Tae-woo, then ruling party's chair and presidential candidate, bowed to strong public pressure for democratic reforms, including direct presidential elections. And, in December that year, Roh was barely elected to the presidency, winning only about $36 \%$ of the popular votes. Moreover,

22) Byung-Sun Choi, "Financial Policy and Big Business in Korea: The Perils of Financial Regulation," in Stephan Haggard, Chung H. Lee, and Sylvia Maxfield, eds., The Politics of Finance in Developing Countries (Ithaca, N.Y.: Cornell University Press, 1993), p.42.

23) See World Bank, Korea: Managing the Industrial Transition (Washington, D.C.: World Bank, 1987), p.92.

24) NBFIs, which include investment and finance companies and life insurance companies, have been mainly owned by leading chaebol groups and relatively free from government control. For more details, see Choi (1993), p.31 and 45-47.

25) See Sung-Tae Ro, "Korean Monetary Policy," in Stephan Haggard et al., Macroeconomic Policy and Adjustment in Korea, 1970-1990 (Cambridge: Harvard University Press, 1994), p.173; and Clifford (1994), pp.243-44 and 252 (fn. 19).

26) On the last point, see Ziya Önis, "The Logic of the Developmental State," Comparative Politics 24 (October 1991), p.121. 
in the National Assembly election held in April 1988, his party failed to secure a majority. Under Roh's weak government, political democratization led to a strong demand for economic democratization, thus reducing the autonomy of economic bureaucrats from politics. Indeed, during 1988, some business leaders raised their voices to promote a 'market economy' under private leadership. As an example, Koo Jakyung, chairman of the Federation of Korean Industries (FKI; a potent lobbying organization representing the interests of big business) expressed the growing sentiments among the chaebols by demanding in public that the government should refrain from intervening in the economy. Moreover, Koo also declared that the private sector would no longer agree to every policy of the government and would voice its objection clearly to the government policies conflicting with business interests. ${ }^{27)}$ In this situation, the Blue House (the Office of the President) and the Economic Planning Board (EPB) almost gave up their role of 'coordinator' as the Blue House also put much stress on 'an economy led by the private sector, not by the bureaucrats.' As a result, private businesses became 'unwilling' to provide due information to the government, thus making it more difficult for even the Ministry of Commerce and Industry (MCI) to have a good grip of private business activities. ${ }^{28)}$

On the other hand, political democratization gave more room for chaebol groups to exert their influence on the government through the contribution of campaign funds. For example, at a press conference in October 1988, the FKI chairman Koo announced that the Federation would henceforth collect all political funds openly within business circles and distribute the funds only to the political parties supporting a free-market economy. This statement was indeed a warning to Roh's ruling party that chaebol groups intended to use their economic power to push the government to allow more 'private autonomy and leadership' in the economy. ${ }^{29)}$ In short, with the democratic transition since 1987, Korea's big business became much more active in calling for private autonomy and leadership in the economy, while the government was further unable to control, monitor, and coordinate the business activities of chaebol groups.

So far we have reviewed the changed relations between government and business in Korea during the Chun-Roh years with a view to considering the general business climate in which Korean private businesses' economic exchanges with China were

27) See Kim (1997), p.199; and Carter J. Eckert, "The South Korean Bourgeoisie: A Class in Search of Hegemony," in Hagen Koo, ed., State and Society in Contemporary Korea (Ithaca, N.Y.: Cornell University Press, 1993), p.108.

28) Bae Chul-soo, "Economic Democratization: No Pain, No Gain," Business Korea, August 1988, pp.29-30.

29) See Eckert (1993), p.109. 
conducted. From this review, we have seen that the government-business relations under the Chun and Roh regimes can be characterized as growing mutual distrust, antagonism, and competition, thus no longer corresponding with the conventional image of "Korea, Inc." usually characterized by close public-private consultation and cooperation. That is, the government-dominated symbiotic partnership under the previous regime was much changed under the Chun and Roh regimes. In particular, with the financial liberalization in the early 1980s, the Korean government came to lose its most effective tools for eliciting business compliance or cooperation with government policies and direction, while big businesses enhanced their financial autonomy by reducing their dependence on government-controlled finance. As a result, the chaebols became better able to resist, evade, and even challenge government policies and direction, while the government was gradually unable to control, monitor, and coordinate the activities and behavior of chaebol groups. Moreover, this tendency was intensified both by the growing discord between the two due to the government's antichaebol campaigns and by the strong demands for economic democratization from the chaebols following the democratic transition in 1987.

Here, the point to stress is that during the Chun-Roh years, Korean chaebol groups were no longer 'passive agents' of their government as in the previous years; and the government was also in no position to force the chaebols to comply or cooperate with its policies and directives. ${ }^{30}$ Thus, as some scholars have also observed, it was quite difficult for the Korean government to control or manipulate the activities and behavior of the private sector, especially for political purposes. ${ }^{31)}$ Then, under such a changed business climate, it seems certain that Korean chaebol groups' economic exchanges with China were neither conducted in close cooperation and consultation with their government nor made possible by the government's close control and direction. This tentative conclusion will be confirmed by more circumstantial and empirical evidence supporting the nongovernmental nature of Korean businesses' economic exchanges with China.

\section{The Circumstantial and Empirical Evidence}

Besides the changes in government-business relations, there are still other factors that acted as constraints on the South Korean government's active intervention in private business' economic exchanges with China. First of all, it is to be mentioned that under the Chun regime (1980-88), the ultimate goal of South Korea's foreign policy was

30) See Moon (1994), p.161; Moon (1988), p.82; and Kim (1997), p.197.

31) See Moon (1988), p.82; and Önis (1991), p.121. 
'to maintain peace and prevent another war on the Korean peninsula.' In this vein, as former President Chun himself has said, his government tried to approach China to achieve its top foreign policy goal, that is, the prevention of war on the Korean peninsula. ${ }^{32)}$ The South Korean government's consistent logic was well represented in Chun's own remarks made in December 1980 and October 1984 that:

If our country expands trade with the communist world, including Red China, through third countries if necessary, North Korea will find itself in a state of diplomatic and economic isolation and will eventually respond to our calls for bilateral trade and other exchanges.

If China shows its intention to open relations with [South] Korea, it will make a great contribution to the stability in Northeast Asian region. Such a Chinese stance will be an affirmative ingredient to deter North Korea from provoking a war on the Korean peninsula. ${ }^{33)}$

Therefore, it becomes clear that from the Chun government's point of view, South Korea's approach to China was just a means of achieving its top foreign policy objective; thus, priority in its economic exchanges and contacts with China was given to security and political interests, rather than to pure economic profit.

Moreover, under the context of Sino-Soviet rivalry for political influence over North Korea during the first half of the 1980s, the Chun government's somewhat naive intention to disrupt China's traditional ties with North Korea by improving South Korea's relations with China through private economic exchanges, however, was sure to conflict with Beijing's efforts to sustain a close political relationship with North Korea. Therefore, considering the quite 'sensitive' position of Beijing not to offend the North unduly, the South Korean government's direct intervention in private businesses' economic exchanges with China would have been 'neither desirable nor helpful' in promoting private economic links with the Chinese. In this view, it is true that South Korea's unofficial trade and economic exchanges with China were closely connected with the government's security and political interests; but, in reality, there seemed little

32) Sanghyun Yoon, "South Korea's Nordpolitik with special reference to its relationship with China” (Ph.D. diss., George Washington University, 1994), p.296.

33) See Seoul Domestic Service, 1 December 1980, in Foreign Broadcast Information Service (FBIS), Daily Report: Asia and Pacific (hereafter FBIS-Asia), 3 December 1980, E9, and Korea Times, 2 November 1984, in FBIS-Asia, 2 November 1984, E1, respectively. 
room for the Korean government to play any 'significant' role except to leave the matters in the hands of private businesses and to reduce or remove barriers to their trade and other economic exchanges and contacts with the Chinese.

On the other hand, the nongovernmental nature of Korean private businesses' economic exchanges with China can also be found in keen competition among rival companies for the initiative in penetrating the China market. By the mid-1980s, Korea was in great need of finding new export markets due to growing foreign competition and mounting protectionist pressure from its major trading partners, especially the United States. In this situation, by early 1985, as many as 40-50 Korean trading companies in Hong Kong were running a tight race for more China trade. ${ }^{34)}$ Moreover, during the same year, Korea's Daewoo and Samsung groups each opened an office in Beijing in June and September, respectively. While these unofficial offices were nothing more than 'liaison offices' of the two chaebol groups' subsidiary companies based in Hong Kong, the opening of such offices one after another was a result of competition between these two rival business groups which had long sought to secure a foothold for expanding their China trade. ${ }^{35}$ By the end of the year, as more Korean companies rushed to the new export market of China and thus the competition for the China trade became all the more fierce, the Korean government was finally placed in a position to rather discourage 'overheated' competition among domestic companies for the China market; indeed, by November 1985, the Ministry of Commerce and Industry (MCI) had organized a 'special committee' with the aim of discouraging private businesses from competing 'too fiercely' for the lead in making inroads into the China market. ${ }^{36)}$

In the meantime, during the three consecutive years of 1986-88, South Korea witnessed an unprecedented export boom and big trade surpluses, which in turn led to trade friction with its major trading partners, the United States and Europe. Thus, even for the purpose of avoiding trade disputes, big Korean chaebol groups made further efforts to advance into the new potential market in China; as an initial effort, by late 1986, most of major chaebol groups had set up their special 'task force' teams in charge of trade and related business with China. ${ }^{37)}$ Besides the trade with China, after mid-

34) Washington Post, 28 April 1985, A21 and A25.

35) Of all the Korean chaebols, Samsung and Daewoo were most active in advancing into the China market. On their Beijing offices, see FBIS-EAS, 16 October 1990, p.34; 25 October 1990, p.33; and 12 December 1990, pp.26-27.

36) Korea Herald, 10 November 1985, in FBIS-Asia, 14 November 1985, E1.

37) On the China 'task force' teams, see Hong Kwon-hee, "Junggong baram e seoleneun jaegae punghyang" [The 'China Wind' blowing in Korean business circles], Shin Dong-a, March 1988, p.370. 
1987, Korean companies came to have a greater interest in joint ventures with China due to dramatic wage hikes in Korea caused by a huge number of strikes in the wake of the so-called 'June 29 democratization pledges' made by Roh Tae-woo. ${ }^{38)}$ Moreover, spurred by Roh's friendly gestures toward China during late 1987 and early 1988, both Korean businessmen and the general public were all caught up in a 'China fever,' which reached its height with the 1988 Summer Olympic Games opening in Seoul. ${ }^{39)}$ Accordingly, the competition among Korean private businesses for trade and joint ventures with China became much more fierce.

In face of the China fever, the Korean government's economic officials such as Vice Minister of the Economic Planning Board (EPB) Moon Hi-gab advised Korean companies to be cautious in doing business with China and to concentrate first on trade rather than direct investment to reduce their risks. ${ }^{40)}$ And, in February 1989, Deputy Prime Minister (and Minister of the EPB) Cho Soon also said that the government would ask domestic firms to carefully consider possible risks in business dealings with China and would urge them not to push forward economic exchanges with China in a hasty manner. ${ }^{41)}$ Subsequently, in March 1989, the EPB decided that Korean investments in China (and other communist countries) exceeding $\$ 1$ million be subject to prior government approval. ${ }^{42)}$ Again, in September 1990, the Korean government announced its plan to form a 'special committee' that would regulate excessive competition among Korean companies in China and other communist countries. ${ }^{43)}$

In view of the above, it is clear that the heightened enthusiasm of Korean private businesses for the China market often outpaced their government's intention or policy. As seen above, Korean private companies' competition for trade and joint ventures with China was fierce to the extent that even the Roh government, which was committed to promoting private trade and economic exchanges with China, sought to discourage

38) Following the democratization pledges in June 1987 made by Roh Tae-woo (then ruling party's presidential nominee), more than 3,600 strikes erupted across the country during the second half of 1987 alone.

39) By 1988, all of Korea's top 10 chaebol groups and over 100 smaller companies were involved in China business (see Dan C. Sanford, South Korea and the Socialist Countries: The Politics of Trade [New York: St. Martin's Press, 1990], p.112, fn.10).

40) Business Korea, November 1988, p.24.

41) Korea Herald, 17 February 1989, in FBIS-EAS, 22 February 1989, p.49. Indeed, about this time, Korean news media also expressed great concern for 'indiscreet' competition among Korean businesses in China and other communist countries (see FBIS-EAS, 10 January 1989, pp.21-22; and 31 January 1989, p.27). In addition, during the period under study, most of Korea's economic exchanges with communist countries were conducted with China.

42) Yonhap, 20 March 1989, in FBIS-EAS, 22 March 1989, p.30.

43) Korea Times, 23 September 1990, in FBIS-EAS, 24 September 1990, p.31. 
excessive competition by Korean companies in the China market and urged them to refrain from making large-scale investments in China. These circumstances thus suggest that Korean private businesses' trade and economic exchanges with China were conducted by their own decisions, at their own risks, not by the Korean government's close control or direction. ${ }^{44)}$

In sum, South Korean private businesses' economic exchanges and contacts with China were closely linked to their government's security and political interests; and the South Korean government did not conceal its willingness to open and improve relations with China through nongovernmental economic exchanges and contacts; however, in the face of Beijing's quite sensitive and cautious position not to offend North Korea in the context of Sino-Soviet rivalry for more influence over the North during the first half of the 1980s, there seemed little room for the South Korean government to directly intervene in such private business activities with China except to provide a favorable environment for Korean businesses' trade and other economic contacts with the Chinese. Moreover, considering both the overall changes in government-business relations and the sharp competition among rival Korean companies for the China market since the mid-1980s, it seems certain that the South Korean government was neither in a position nor had any need to push private businesses to go to the China market.

In fact, aside from all the circumstantial evidence we have presented so far, there is also 'empirical' evidence supporting the nongovernmental nature of Korean businesses' economic exchanges with China. Indeed, when interviewed by an American scholar in late 1988, the chief executive officers (CEOs) of some of major Korean companies stated outright that they were pursuing business deals with China (and other communist countries) not due to government prodding but basically for their own interests. ${ }^{45)}$ Likewise, many other businessmen also insisted that their interest in the communist markets had been generated by themselves and that no one in their government had asked them to run a risk in seeking business opportunities in these communist markets. Moreover, leading business organizations (including the FKI) admitted that much of their knowledge of government policy was learned through personal or informal gatherings with high-level government officials and through the newspapers, rather

44) For example, one executive of Korea's Daewoo business group, who had long been involved in Daewoo's China projects, said in early 1989 that in dealing with the communist-bloc countries with which Seoul had no diplomatic relations, Korean businesses "must be prepared to take risks" and "need to develop a bold strategy for penetrating these markets." See Joong-ang Ilbo (Seoul), 11 January 1989, in FBIS-EAS, 8 March 1989, p.27.

45) See Dan C. Sanford, "ROK's Nordpolitik: Revisited," Journal of East Asian Affairs 7 (Winter-Spring 1993), p.5; and Sanford (1990), p.126 (fn.44 and 45). 
than direct memos or such from relevant government ministries. ${ }^{46)}$

Furthermore, Whang In-Joung, who served as deputy director of the International Private Economic Council of Korea (IPECK) over 1988-91, confirmed that in spite of the Roh government's political considerations for improving relations with China and other socialist countries, it was the private sector that took the initiative in Korea's unofficial economic exchanges with these countries. ${ }^{47)}$ In direct relation to China, Whang made it clear that the Korean government was 'not involved' in any of Korean investments in China and that such investment decisions were made by private companies according to their own business motives. Most important, he affirmed that in the context of political liberalization during the Roh years, "neither IPECK nor the government could control and coordinate [Korea's] business traffic" with China (and other socialist countries). ${ }^{48}$

\section{The Government's Financial Support}

Now, before closing our discussion of the nongovernmental nature of Korean businesses' economic exchanges with China, we need to mention here that under such nongovernmental economic relations with China, the actions taken by the Korean government were not limited to its attempts to control or regulate private businesses' economic activities. In fact, the government also sought to encourage or promote private economic exchanges with China. For example, in the late 1980s, the Roh government began to provide 'financial support' for the private businesses engaged in trade and investment activities with China (and other communist countries). ${ }^{49)}$ Nevertheless, there is little doubt that the government backing (esp., financial support) did not affect the

46) Sanford (1990), p.87.

47) In-Joung Whang, "Korea's Northern Policy: A Response to a Changing World Order," in Il Yung Chung, ed., Korea in a Turbulent World: Challenges of the New International Political Economic Order and Policy Responses (Seoul: Sejong Institute, 1992), p.433. In addition, IPECK (which was set up in October 1988 by 265 private firms and major business organizations, operated with formal and informal support from the Korean government, and merged into a government-funded think tank under the EPB in January 1992) was a "semigovernmental' organization designed to promote, monitor, control and coordinate Korean private companies' trade and other economic exchanges with socialist countries, especially China, on behalf of the government. For this reason, Whang, who was IPECK's deputy director in charge of practical affairs, is considered as one of the most reliable sources who can provide correct information on the questions under study.

48) See ibid., p.444 and 452.

49) Included among the government's financial support were export financing, export insurance, political risk insurance, and government-approved preferential soft loans for investment. See Thomas E. Jones, "Gaining Visibility: Sino-South Korean commerce is becoming too big to hide," China Business Review, November-December 1990, p.48 and 50. 
nongovernmental nature of private businesses' economic activities with China. Indeed, considering the tireless enthusiasm and keen competition among Korean companies for the China market as well as strong financial power of the chaebols, it seems right to say that even without financial support from the government, Korean private businesses (esp., chaebol groups) would have carried on with their China projects anyway. ${ }^{50)}$

Then, why did the Roh government offer financial support to the Korean private companies involved in China business? Of course, the ostensible reason was to assist private companies with their efforts to advance into the China market as a means of achieving the government's own foreign policy goal of improving relations with China. However, there were other significant purposes behind the government's financial support. First of all, by the late 1980s, the Korean economy was in pressing need of 'industrial restructuring,' as Korea had experienced dramatic wage hikes, labor shortages, currency appreciation, as well as sharp trade friction with its major trading partners. Traditional labor-intensive sectors (such as footwear, garment, and toys) were the ones worst hit by the above factors. In this situation, overseas relocation of production lines was considered as a strategic response to the changing domestic and international economic environments. Accordingly, as part of its efforts to promote industrial restructuring, the Roh government took the measure of providing 'preferential soft loans' for domestic firms making investments in China (and other communist-bloc countries). ${ }^{51)}$

Secondly, with its financial support, the Roh government intended to intervene in private businesses' economic exchanges with China. As already mentioned, the government announced in September 1990 its plan to form a 'special committee' to regulate excessive competition among Korean private companies in China and other communist countries. More importantly, the government plan specified the condition that domestic businesses would be required to report to the committee in advance their trade and other economic activities with these communist countries and if they failed to do so, they would face various restrictions on their projects; for example, preferential loans and other financial support to them would be limited. ${ }^{52}$ Here, it is clear that the

50) In this view, it would be misleading to assert that in Korean businesses' economic exchanges with China, the government of Korea "could control big business through its financial support." Such assertions, however, can be found in Sang-hyun Yoon, "Korea's Interest Groups and Foreign Policymaking Process," Korea Focus, July-August 1999, p.52; and Yoon (1994), p.243.

51) On the preferential soft loans, see Yonhap, 9 September 1989, in FBIS-EAS, 14 September 1989, p.26.

52) Korea Times, 23 September 1990, in FBIS-EAS, 24 September 1990, p.31. 
Korean government attempted to make the most of its financial support as a tool for monitoring or regulating private businesses' economic activities with China.

Finally, but not least important, the Roh government seemed to be under great pressure to appear that it was taking the initiative or at least playing a crucial role in Korea's economic inroads into the China market. In fact, Roh intended to gain domestic popular support for his government by pursuing the so-called 'Northern Policy' designed to improve relations with communist-bloc countries, especially China and the Soviet Union. Nevertheless, by early 1989, his government faced criticism from the domestic press that in Korean companies' trade with the communist countries, the government remained a 'spectator' with all the initiative and risks left solely to businessmen. ${ }^{53)}$ In this situation, the Roh government may have expected that by providing financial support for Korean private companies doing business with China, it could get credit for playing the leading role in expanding or developing Korea's unofficial economic exchanges with China.

Taken together, there is no doubt that Korean private businesses' economic exchanges with China were not made possible by the government's financial support. And the motives of the government's financial support were also mixed - 1) to promote industrial restructuring by helping domestic firms relocate their production lines to China, 2) to secure a tool for monitoring or regulating private businesses' economic activities with China, and 3) to give the impression that the government also played a certain role in Korea's unofficial economic exchanges with China without leaving the matters only to private businesses.

\section{Summary and Conclusion}

In this study on the nongovernmental nature of Korean businesses' economic exchanges with China prior to the normalization of 1992, we have reviewed the changes in government-business relations during the Chun-Roh years with a view to considering the general business climate under which South Korea's unofficial economic exchanges with China were conducted mainly by Korean private businesses, especially chaebol groups. From the review, we have found that government-business relations under the Chun-Roh regimes no longer correspond with the conventional image of "Korea, Inc." usually characterized by close public-private consultation and cooperation.

53) See Joong-ang Ilbo, 11 January 1989, in FBIS-EAS, 8 March 1989, p.27. 
In particular, with the financial liberalization in the early 1980s, the Korean government came to lose its most effective tools for eliciting business compliance or cooperation with government policies and direction, while chaebol groups could enhance their financial autonomy by reducing their dependence on government-controlled finance. As a result, the chaebols became better able to resist, evade, and even challenge government policies and direction; and the government was gradually unable to control, monitor, and coordinate the activities and behavior of chaebol groups. This tendency was intensified both by the growing discord between the two due to the government's anti-chaebol campaigns and by the strong demands for economic democratization from the chaebols following the democratic transition in 1987. In short, during the Chun-Roh years, Korean chaebol groups were no longer 'passive agents' of their government as in the previous years; and the government was also in no position to force the chaebols to comply or cooperate with its policies and directives. Such a changed business climate suggests that Korean chaebol groups' economic exchanges with China were neither conducted in close cooperation and consultation with their government nor made possible by the government's close control and direction.

On the other hand, more circumstantial and empirical evidence available confirms the nongovernmental nature of Korean businesses' economic exchanges with China. It is true that Korean private businesses' economic exchanges and contacts with China were closely connected with their government's security and political interests. However, in the face of China's quite sensitive position not to offend North Korea in the context of Sino-Soviet rivalry for more influence over the North during the first half of the 1980s, there was little room for the South Korean government to directly intervene in such private business activities with China. Moreover, the heightened enthusiasm of Korean private businesses for the China market outpaced their government's intention or policy. Indeed, Korean private companies' competition for trade and joint ventures with China was fierce to the extent that the Korean government was to discourage excessive competition among Korean companies for the China market and to urge them to refrain from making large-scale investments in China. These circumstances thus support that the South Korean government was neither in a position nor had any need to push private businesses to go to the China market. Finally, empirical evidence also confirms that Korean private businesses' trade and other economic activities with China were conducted by their own decisions, on their own initiative, for their own interests, and at their own risks, not by their government's close control, coordination or direction.

As mentioned at the outset, no previous study has been done on the question as to the nongovernmental nature of Korean businesses' economic exchanges with China prior to 
the normalization of South Korea-China relations in 1992. In this view, the conclusions from this initial study on the subject would be of great significance for academic researchers who are interested in theoretical studies on South Korea's unofficial relations with China in general and South Korea's transnational economic relations with China prior to 1992 in particular. 


\section{REFERENCES}

Amsden, Alice, Asia's Next Giant: South Korea and Late Industrialization, (New York: Oxford University Press), 1989.

Bae Chul-soo, "Economic Democratization: No Pain, No Gain," Business Korea, August 1988.

Choi, Byung-Sun, "Financial Policy and Big Business in Korea: The Perils of Financial Regulation,” in Stephan Haggard, Chung H. Lee, and Sylvia Maxfield, eds. The Politics of Finance in Developing Countries, (Ithaca, N.Y.: Cornell University Press), 1993.

Choi Cheong-lim, "Hanguk eun jaebeol gonghwaguk inga" [Is Korea the Republic of Chaebols?], Wolgan Chosun [Monthly Chosun], October 1986.

Chung, Jae Ho, "South Korea- China Economic Relations: The Current Situation and Its Implications," Asian Survey 28 (October 1988).

Clifford, Mark, "Seoul' s Chinese puzzle," Far Eastern Economic Review, 3 March 1988.

Clifford, Mark L., Troubled Tiger: Businessmen, Bureaucrats, and Generals in South Korea, (Armonk, N.Y.: M. E. Sharpe), 1994.

Delfs, Robert, "Seoul's hi-tech lure across the Yellow Sea," Far Eastern Economic Review, 8 December 1988.

Eckert, Carter J., "The South Korean Bourgeoisie: A Class in Search of Hegemony," in Hagen Koo, ed., State and Society in Contemporary Korea, (Ithaca, N.Y.: Cornell University Press), 1993.

Ensor, Paul, “Grains of a secret," Far Eastern Economic Review, 4 April 1985.

Haggard, Stephan and Chung-in Moon, "Institutions and Economic Policy: Theory and a Korean Case Study,” World Politics 42 (January 1990).

Hong Kwon-hee, "Junggong baram e seoleneun jaegae punghyang" [The 'China Wind' blowing in Korean business circles], Shin Dong-a, March 1988.

Johnson, Chalmers, "Political Institutions and Economic Performance: The GovernmentBusiness Relationship in Japan, South Korea, and Taiwan,” in Frederic C. Deyo, ed. The Political Economy of the New Asian Industrialism, (Ithaca, N.Y.: Cornell University Press), 1987.

Jones, Leroy P. and Il SaKong, Government, Business, and Entrepreneurship in Economic Development: The Korean Case, (Cambridge: Harvard University Press), 1980. 
Jones, Thomas E., "Gaining Visibility: Sino-South Korean commerce is becoming too big to hide," China Business Review, November-December 1990.

Kim, Eun Mee. Big Business, Strong State: Collusion and Conflict in South Korean Development, 1960-1990, (Albany, N.Y.: State University of New York Press), 1997.

Lho Joo-hyoung, "Korea Looks West - To China," Korea Business World, July 1988.

Moon, Chung-in, "The Demise of a Developmentalist State?: Neoconservative Reforms and Political Consequences in South Korea," Journal of Developing Societies 4 (1988).

Moon, Chung-in, "Changing Patterns of Business-Government Relations in South Korea," In Andrew MacIntyre, ed., Business and Government in Industrializing Asia, (Ithaca, N.Y.: Cornell University Press), 1994.

Önis, Ziya, "The Logic of the Developmental State," Comparative Politics 24 (October 1991).

Rhee, Jong-Chan, The State and Industry in South Korea: The Limits of the Authoritarian State, (New York: Routledge), 1994.

Ro, Sung-Tae, "Korean Monetary Policy," in Stephan Haggard et al., Macroeconomic Policy and Adjustment in Korea, 1970-1990, (Cambridge: Harvard University Press), 1994.

SaKong, Il, Korea in the World Economy, (Washington, D.C.: Institute for International Economics), 1993.

Sanford, Dan C., South Korea and the Socialist Countries: The Politics of Trade, (New York: St. Martin's Press), 1990.

Sanford, Dan C., "ROK's Nordpolitik: Revisited," Journal of East Asian Affairs 7 (Winter-Spring 1993).

Tanzer, Andrew, "A diplomatic defection," Far Eastern Economic Review, 26 November 1982.

Uhm Ji-do, "No daetongryeong ui jaebeol gwa ui jeonjaeng"[President Roh's war against the chaebols], Wolgan Chosun [Monthly Chosun], June 1992.

Wade, Robert, Governing the Market: Economic Theory and the Role of Government in East Asian Industrialization, (Princeton, N.J.: Princeton University Press), 1990.

Whang, In-Joung, "Korea's Northern Policy: A Response to a Changing World Order," in Il Yung Chung, ed., Korea in a Turbulent World: Challenges of the New International Political Economic Order and Policy Responses, (Seoul: Sejong Institute), 1992. 
Woo, Jung-en, Race to the Swift: State and Finance in Korean Industrialization, (New York: Columbia University Press), 1991.

World Bank, Korea: Managing the Industrial Transition, (Washington, D.C.: World Bank), 1987.

Yoon, Sanghyun, "South Korea's Nordpolitik with special reference to its relationship with China” (Ph.D. diss., George Washington University), 1994.

Yoon, Sang-hyun, "Korea's Interest Groups and Foreign Policymaking Process," Korea Focus, July-August 1999.

Foreign Broadcast Information Service (FBIS), Daily Report: Asia and Pacific (FBISAsia)

Foreign Broadcast Information Service (FBIS), Daily Report: East Asia (FBIS-EAS)

* Newspapers: Christian Science Monitor, Los Angeles Times, Wall Street Journal, Washington Post

* Magazines: Economist, Business Korea 